\title{
Research on the Income Volatility of Listed Banks in China: Based on the Fair Value Measurement
}

\author{
Pingsheng Sun, Xiaoyan Liu \& Yuan Cao \\ School of Economics and Management, North China Electric Power University, Beijing 102206, China \\ E-mail: liuxy@ncepu.edu.cn
}

Received: April 1, 2011 Accepted: April 14, 2011 doi:10.5539/ibr.v4n3p228

The research is financed by the Fundamental Research Funds for the Central Universities. (Sponsoring information)

\begin{abstract}
The explosion of financial crisis induced an argument about the accounting of fair value in the whole world, and the influence of the fair value measurement on the bank profit begun to be noticed by the public. In the background that Chinese commercial banks successively implemented the shareholding reform and begun to come into the market, it is practical and meaningful to analyze the influence of the fair value measurement on the income volatility of listed banks. The relationship between the fair value and the income volatility can be found by the empirical study of the income volatility of listed banks of China. The research result shows that the income volatility induced by the fair value significantly exceeds the results of the historical cost mode and the mixed measurement mode, and the interior volatility of economy is the main cause of the net income volatility of listed banks in China.
\end{abstract}

Keywords: Fair value measurement, Income volatility, Risk prevention

\section{Introduction}

With the change of economic environment and the continual innovation and universal use of financial tools, the accounting of historical cost has not satisfied the demand of the financial development, and both FASB and IASB continually strive for the measurement attribute of the fair value as the financial tool. The authorities of financial supervision have always worried about the comprehensive use of fair value would increase the volatility of financial report, and influence the stability of financial system on the macro layer. The explosion of financial crisis attracted the public to the influence of the fair value on the income volatility of banks again.

To harmonize the accounting principle of China with the principle of international financial report, China issued new enterprise accounting principle system in Feb, 2006, including four accounting principles about financial tools. After introducing the fair value measurement, the financial state and management result of Chinese listed banks will be more closely associated with changeable capital market and the macro-economic environment of China, which will further strengthen the volatility of the income and capital of Chinese listed banks. In the background that Chinese commercial banks successively implemented the shareholding reform and begun to come into the market, it is practical and meaningful to analyze the influence of the fair value measurement on the income volatility of listed banks.

Before the financial crisis happened, the foreign research literatures about fair value mainly discussed the measurement attribute of fair value and empirical tested the decision-making usability of fair value information. After the financial crisis, the research of the economic result of fair value had been largely noticed by the public. Hodder et al (2006) discovered that the income volatility measured by the fair value method was bigger three times than the income volatility measured by the comprehensive income method through the sample analysis, and was bigger five times than the income volatility measured by the historical cost, and the authors thought that the result reflected the fair value method could captured more risk factors about the pricing of risks in the capital market. Allen et al (2006) thought that the fair value could induce the infection effect of the financial market, trigger the reduction sale of bank assets, and strengthen the correlation and volatility of the market.

The standard research method is mainly adopted in the Chinese literatures about the fair value. Xu Yude thought that the accounting principle had economic consequences, and in the special situation that the financial crisis had spread to the whole world, the accounting principle of fair value should be modified properly or its application in the special financial tool should be given up temporarily (Xu, 2009, P. 35-46). Xu Sheng thought that the volatility of financial report induced by the fair value measurement could be overcome by extracting dynamic value decrease preparation (Xu, 2009, P. 14-19). Comparing with foreign researches, the empirical researches in this domain are rare, which may be because that the application time of the fair value measurement was short, and the amount of 
listed banks was less. With the comprehensive push of the new accounting principle in 2006, and the amount of listed banks in China continually increases, very good data base have been prepared for the research of this problem. Through the analysis and research of the financial report and data about the listed banks in China, the relationship between fair value and income volatility will be studied as follows.

\section{Analysis of the income volatility of listed banks in China}

\subsection{Sample selection and data sources}

The amount of financial tools hold by financial enterprises is obviously more than other industries, and it is more representative to study the influence of the fair value measurement on the income volatility, so fourteen listed banks in the A share market of China are selected in this article as the research samples. To ensure the comparability of number, the report numbers compiled according to the new principle are only selected.

Along with that the document No.14 of the Finance Department of China, "Temporary Regulation about the Confirmation and Measurement of Financial Tools (Trail)" was implemented in 2006, the volatility of the fair values of financial assets and financial debts about financial listed companies was confirmed in the table. Before 2006, many banks had correspondingly adjusted the fair values according to the principals in the new accounting principle to make the net income and net assets in the foreign and domestic reports to be consistent, and the comparable numbers in report of 2005 were also adjusted correspondingly according to the new principle. Therefore, the numbers in the reports of listed banks from 2005 to 2009 all accord with the sampling requirements in this article.

Because the annual reports of listed banks have all been audited by the accounting firm, with higher credibility and accuracy rate, the research data in the article all come from the audited annual reports of all listed banks.

\subsection{Income volatility of listed banks}

The research target of this article is to make clear the relationship between the fair value measurement and the income volatility. The income volatility can be embodied by the key index, net income, which is the linkage to link the balance sheet and the income statement, and it can not only reflect the present management result of enterprise, but also reflect the change of owners' equity, and its volatility is very important for the report. Based on the research target of this article, one feasible research method is to respectively compute the net incomes in the historical cost measurement mode, in the mixed measurement mode, and the fair value measurement mode, and judge in which mode the volatility of net income is the biggest one.

According to above research ideas, following methods are used to process the data of reports.

(1) Net income of historical cost $=$ present net income - changeable gains and losses of fair value

(2) Net income of mixed measurement $=$ present net income

(3) Net income of fair value $=$ present net income + net change sum of fair value of salable financial assets

To compare net incomes and eliminate the influence of the scale of bank assets on the absolute amount of net income, after computing different net incomes under three kinds of measurement modes, the relative amount of the net income relative to the asset scale needs to be computed and the concrete computation formulas are

(4) Net income of comparable historical cost $=$ net income of historical cost/ sum of average asset

(5) Net income of comparable mixed measurement = income of mixed measured/ sum of average asset

(6) Net income of comparable fair value $=$ net income of fair value/ sum of average asset

(7) Sum of average asset = (sum of year-beginning assets + sum of year-end assets) $/ 2$

The data processing results of fourteen listed banks from 2005 to 2009 in the A Share Market are seen in Table 1 by the descriptively statistical way.

To more clearly reflect the volatilities of three measurement modes, the standard deviations of each year in the research periods of three measurement modes are plotted, as seen in Figure 1.

\subsection{Result analysis}

From the item of "mean value of standard deviation", it is obvious that fair value $>$ mixed measurement $>$ historical cost, according to the volatilities of three measurement modes. The result of Figure 2 also proves this conclusion, and the line of the net income of the comparable fair value is obviously above another two lines, which indicates that the volatility of the fair value measurement mode is the biggest one. The lines of the net income of mixed measurement and the net value of the comparable historical cost are almost polymerized, which means that the volatilities of these two measurement modes are almost same, but the volatility of the mixed measurement mode is a little bigger than the volatility of the historical cost measurement mode. 


\section{Causes for the income volatility of listed banks in China}

\subsection{Interior volatility of economy}

The interior volatility means the volatility of fair value, and the fair value of assets or debts in the next period may be different with the fair value in this period because of the change of the market environment such as interest rate, so the financial reports will change, but the volatility of financial reports is economic volatility, and the financial reports can reflect this economic volatility. The interior volatility of financial reports is not the consequence of accounting, but the reflection of accounting in the economic reality. The users of financial reports are more interested in the future estimation of fair value, which also depends on the state of future world. So the fair value is changeable, and the measurement is also changeable, and this interior volatility is not the problem of accounting in essential.

To further analyze the cause of the volatility of net income of banks, and the following research period will be extended to the year of 2000. At the same time, to analyze the relationship between the volatility of net income of listed banks and the interior volatility of macro economy, the mean values of SZZS and the base interest rate of one-year loan are introduced in this article.

As the important measure to control and adjust the macro economy, the adjustment of interest rate is usually presented as enhancing interest rate when the economy rises high, and reducing interest rate when the economy is excessively low. Therefore, the adjustment of interest rate accords with the economic period, with obvious characteristic of periodicity. As a kind of period with derived characteristic, the adjustment period of interest rate will change with the periodical change of macro economy correspondingly.

The macroeconomic activities and the macroeconomic policies will influence the share market as a whole. The prosperity state of the macro economy will influence the prosperity state of most industries, and the prosperity state of the industry will influence the management performance of most companies, and the management performance of the company will influence most common stock sharers' incomes and investment return rates, and accordingly influence the price of most common stocks, and finally influence the stock indexes. Therefore, the macro economy is the most basically decisive factor in the securities market.

In Figure 2, by adjusting the data sizes, the annual change curves of net incomes, the annual change curve of the average value of SZZS, and the base interest rate change curve of one-year loan from 2000 to 2009 are plotted.

In Figure 2, three curves increase and decrease at the same time, and they are correlative each other. To further confirm the scale of correlation, the bivariate correlation analysis results of the net income, the average value of indexes, and the base interest rate of SZZS are seen in Table 2. From correlation analysis, the correlative coefficients of net income and the average value of SZZS are significantly positive correlative, and the correlative coefficient is 0.916 , and the significance level of this correlative coefficient sig. (two sides) $=0.000$ is highly significant, with high correlative tendency. From Table 2, the correlative coefficients of the net income and the interest rate of one-year loan are significantly positively correlative, and the correlative coefficient is 0.625 , and the significance level of the correlative coefficient sig. (two sides) $=0.053$ is middle-level significant, with middle-level correlative tendency. By the correlation analysis, the conclusion shows that the volatility of net incomes of listed banks is mainly induced by the interior volatility of economy.

Further research shows that the income volatility of listed banks and the interest margin of banks change consistently. In Figure 2, the curve of net income steps in trough from 2002 to 2005, and the interest margin at the same period keeps at $3.33 \%$ all the time, which means that the decrease of interest margin induced the decrease of the net income of listed banks. In the next years, with the rise of interest margin, the net income of listed banks increases significantly, and the increase extent in 2007 is the biggest one. In 2008 and 2009, though the interest margins were at the historical low position in past ten years, but the net income of listed banks kept at the higher position, because China performed loose monetary policy in this period, and the credit scale extended drastically, and the banks could obtain the scale income.

Based on above analysis, the net income of listed banks is directly associated with the interest margin of loan and deposit, and the change of interest rate belongs to the reflection of the interior volatility of economy, which also means that the income volatility of listed banks in China comes from the interior volatility of economy.

\subsection{Income volatility of reports because of mixed measurement}

Up to now, there is not a uniform measurement mode for all assets and debts in China, that is to say, some assets are measured according to the historical cost, and some assets are measured according to the cost and the present value, and some assets are measured according to the fair value, and some assets are not measured. As a result, the influence of the economic items to all assets and debts cannot completely be reflected in financial reports. For 
example, when the assets are measured according to the fair value and the bonds with fixed rate are confirmed according to the historical cost, the market interest rate increase and the value of assets reduces, and the decrease will be confirmed in the financial reports, and the value of debts also reduces, but the decrease has not been confirmed in the financial reports, and the increase of interest rate will largely impact the financial reports negatively, and this negative influence will increase the volatility of financial reports. If the assets and debts are measured according to the fair value or the historical cost, the decreases of the market interest rate will cancel out the influence on the assets and the influence on the debts, so one of direct results of the mixed measurement accounting system is to increase the volatility of reports.

\subsection{Income volatility because of wrong estimation}

When the market doesn't exist, the fair value must be estimated. Under this situation, the fair value of assets or debts is the present value of their expected cash flow. Because the future cash flow is unknown, so these uncertain results should be estimated. Wrong estimation is an inevitable result when estimating the fair value. Even if the estimation is impartial, the real cash flow may differ from the estimated cash flow. For the fair value obtained from the market price, the wrong volatility is rare. For the fair value obtained from the estimation, the wrong volatility reflects the accuracy rate of estimation.

\section{Conclusions}

From the descriptive statistical result, comparing with old principles, the wide application of new principles in fair value will actually increase the income volatility of listed banks and the whole financial industry. Through the correlative analysis of the volatilities of SZZS, the interest rate of one-year loan, and the net income, it is obvious that the income volatility of listed banks mainly come from the volatility of macro economy, and the measure of fair value can only objectively reflect the real volatility state of macro economy. The volatility of macro economy exists objectively, which will not be changed because of human will. So the income volatility cannot be eliminated from the sources, and the impaction of the volatility of macro economy on the income volatility of listed banks can only be weakened trough the construction of various systems, to maintain the stability of the whole financial system and avoid the occurrence of financial crisis.

\section{References}

LANDSMAN W. R. (2006). Fair Value Accounting for Financial Instruments: Some Implications for Bank Regulation. BIS working paper. No. 209. August.

Leslie D. Hodder, Patrick E. Hopkins, and James M. Wahlen. (2005). Risk-Relevance of Fair Value Income Measurement for Commercial Banks. The Accounting Review. No. 81(2).

Luo, Shengqiang. (2005). Analysis of the Influence of the Fair Value Measurement on the Bank Industry of China. Accounting Research. No. 12. P. 8-13.

Sun, Zhuoyuan. (2008). Analysis of the Relationship between the Stock Market Volatility of China and the Macro Economy Volatility Based on the Yield Rate of Shanghai Stock Market. Ji'nan: Thesis of Master's Degree of Shandong University. May, 2008.

Wang, Shouhai. (2009). Research on the Fair Value and Financial Report Volatility: As Viewed from the Analysis of Subprime Crisis. Modern Accounting. No. 8. P. 27-29.

$\mathrm{Xu}$, Sheng. (2009). Financial Stability and Optimization of Fair Value Accounting: A Dynamic Provision Perspective. Accounting Research. No. 5. P. 14-19.

Xu, Yude. (2009). Fair Value Measurement, Finance Stability, and Risk Prevention: Accounting Rethinking in the Global Financial Crisis. Review of Economic Research. No. 7. P. 35-46. 
Table 1. Descriptive statistics of comparable net incomes

\begin{tabular}{|c|c|c|c|c|c|c|}
\hline \multirow{2}{*}{ Year } & \multicolumn{2}{|c|}{ Comparable net income of historical cost } & \multicolumn{2}{c|}{ Comparable net income of mixed measurement } & \multicolumn{2}{c|}{ Comparable net income of fair value } \\
\cline { 2 - 7 } & Mean value & Standard deviation & Mean value & Standard deviation & Mean value & Standard deviation \\
\hline 2005 & $0.446 \%$ & $0.151 \%$ & $0.454 \%$ & $0.148 \%$ & $0.514 \%$ & $0.131 \%$ \\
\hline 2006 & $0.669 \%$ & $0.238 \%$ & $0.673 \%$ & $0.261 \%$ & $0.663 \%$ & $0.269 \%$ \\
\hline 2007 & $1.036 \%$ & $0.292 \%$ & $1.031 \%$ & $0.281 \%$ & $1.039 \%$ & $0.361 \%$ \\
\hline 2008 & $1.080 \%$ & $0.383 \%$ & $1.124 \%$ & $0.415 \%$ & $1.273 \%$ & $0.586 \%$ \\
\hline 2009 & $1.039 \%$ & $0.212 \%$ & $1.038 \%$ & $0.198 \%$ & $0.948 \%$ & $0.209 \%$ \\
\hline $\begin{array}{c}\text { Mean value from } \\
2005 \text { to 2009 }\end{array}$ & \multicolumn{3}{|c|}{$0.854 \%$} & $0.864 \%$ & & \multicolumn{2}{|c|}{$0.888 \%$} \\
\hline $\begin{array}{c}\text { Standard deviation } \\
\text { from 2005 to 2009 }\end{array}$ & \multicolumn{2}{|c|}{$0.2826 \%$} & & & \\
\hline
\end{tabular}

Table 2. Bivariate correlation analysis

Correlations

\begin{tabular}{|ll|r|r|r|}
\hline & & \multicolumn{3}{|c|}{$\begin{array}{l}\text { Mean value Base interest rate } \\
\text { of SZZS of one-year loan }\end{array}$} \\
\hline Mean value of SZZS & Pearson Correlation & & & \\
& Sig. (2-tailed) & & & \\
& $\mathrm{N}$ & & & \\
\hline Base interest rate of & Pearson Correlation & $.749^{*}$ & & \\
one-year loan & Sig. (2-tailed) & .013 & & \\
& $\mathrm{~N}$ & 10 & & \\
\hline Net profit & Pearson Correlation & $.916^{\star \star}$ & .625 & \\
& Sig. (2-tailed) & .000 & .053 & \\
& $\mathrm{~N}$ & 10 & 10 & \\
\hline
\end{tabular}

${ }^{*}$. Correlation is significant at the 0.05 level (2-tailed).

${ }^{* *}$. Correlation is significant at the 0.01 level (2-tailed).

Table 3. Change of margin between one-year deposit rate and loan rate

\begin{tabular}{|c|c|c|c|}
\hline Year & Loan interest rate (\%) & Deposit rate (\%) & Interest margin (\%) \\
\hline 2000 & 5.850 & 2.25 & 3.600 \\
\hline 2001 & 5.850 & 2.25 & 3.600 \\
\hline 2002 & 5.310 & 1.98 & 3.330 \\
\hline 2003 & 5.310 & 1.98 & 3.330 \\
\hline 2004 & 5.580 & 2.25 & 3.330 \\
\hline 2005 & 5.580 & 2.25 & 3.330 \\
\hline 2006 & 5.985 & 2.52 & 3.465 \\
\hline 2007 & 6.930 & 3.465 & 3.465 \\
\hline 2008 & 6.336 & 3.06 & 3.276 \\
\hline 2009 & 5.310 & 2.25 & 3.060 \\
\hline
\end{tabular}




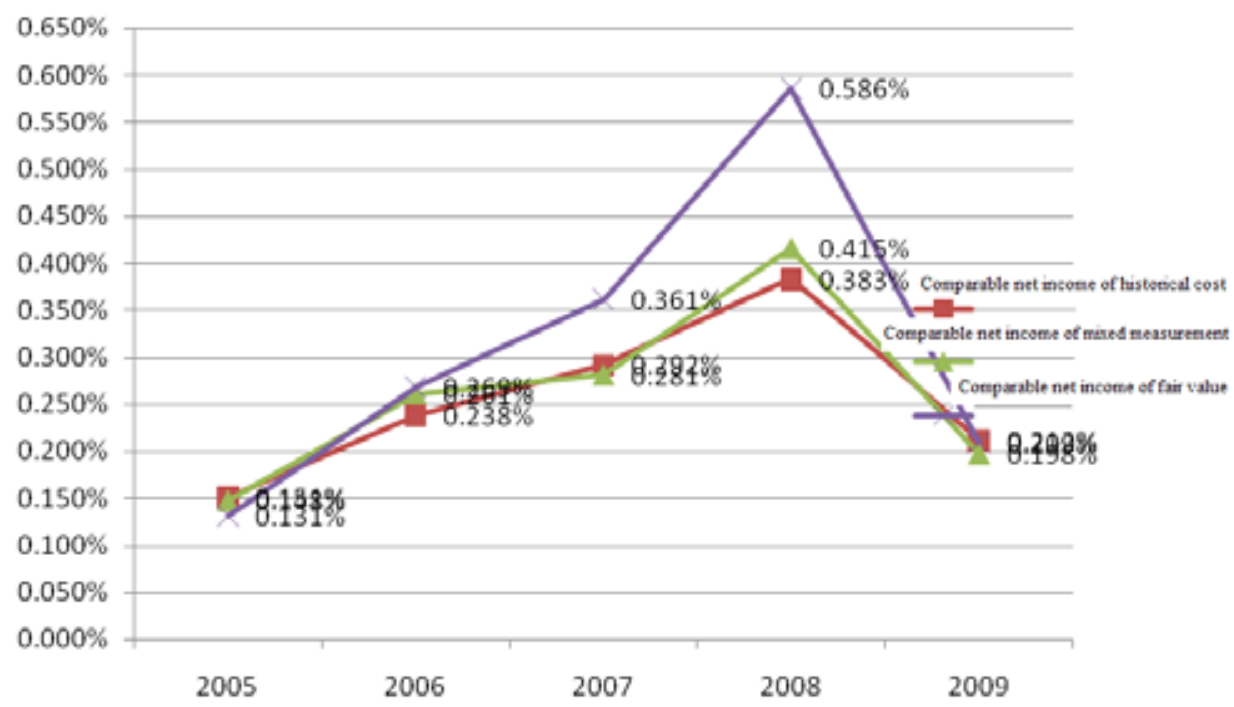

Figure 1. Line Graph of the Standard Deviations from 2005 to 2009

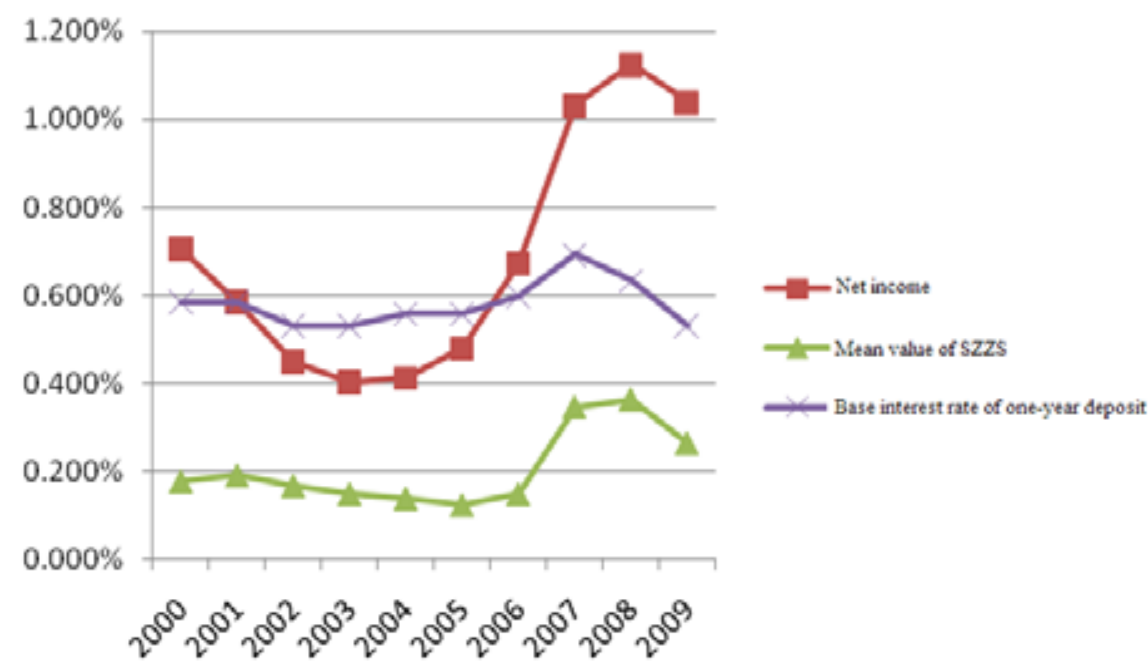

Figure 2. Relation Graph of Net Profit Volatility 